\title{
Monitoring Elementary School Teachers' Approaches to Handling Bullying Among Students
}

\author{
DOI: 10.15804/tner.2021.65.3.17
}

\begin{abstract}
The aim of the study was to map teachers' preferred approaches to handling bullying among students. The scaled Handling Bullying Questionnaire (Bauman et al., 2008) was used. The structure of the research tool was determined using exploratory factor analysis indicating the existence of 5 dimensions. The good fit of the model to the actual data was verified using confirmatory factor analysis returning very good values of the good fit indices (CFI, TLI, RMSEA, SRMR, GFI). 696 teachers of the elementary school second level participated in the research. Their mean age was 46.53 years $(S D=9.34)$ and the mean length of their experience was 21.10 years $(S D=10.44)$. Male teachers scored statistically significantly higher on the dimension „Disciplining the bully“; teachers who had obtained their qualification through a supplementary pedagogical study scored statistically significantly lower on the dimension „Ignoring the incident“ and higher on the dimensions „Enlisting other adults“ and „Disciplining the bully"; class teachers scored statistically significantly higher on the dimension "Working with the bully“; teachers having received anti-bullying training within their continuing education scored statistically significantly higher on the dimensions „Working with the bully“ and „Enlisting other adults“; teachers with functions aimed at sorting out students' problem behaviour scored the lowest on the dimension „Ignoring the incident“. Neglectful and weak effects were identified of the differences in resulting values. Also, a weak direct dependence appeared between working with the bully as the preferred approach and the length of teachers' experience.
\end{abstract}

Keywords: bullying, teacher, intervention, elementary school 


\section{Introduction}

Bullying is a social and educational problem of current interest. The expansion of aggression and hostility among children and young people raises a relentless need to pay attention to this phenomenon. According to Craig et al. (2009) a quarter of students are involved in bullying. Twardowska-Staszek et al. (2018) dealing with validation of questionnaires mapping bullying and cyber-bullying found out high rates of such behaviours among students.

Due et al. (2005) defined bullying by three typical indicators: an imbalance of power, repeated attacks and the intention to harm. Nansel et al. (2001) emphasized that bullying seriously affects youth's social functioning. Victims of bullying may experience deteriorating school performance, mental health issues and physical injuries. Negative change in the school climate as a result of bullying was drawn attention to by Kartal and Bilgin (2009) considering safety the most important component of the school climate. It is the feeling of safety that is the first aspect that is disappearing from the school climate in the case of bullying. According to Macháčková (2010), the safe climate at school is one of the main conditions for effective prevention of bullying.

Professional literature contains various aspects of bullying worked out at a theoretical and empirical level. A significant part of scientific studies focuses on the monitoring and analysis of the prevalence, forms, causes and consequences of bullying (Hymel \& Swearer, 2008; Jan \& Husain, 2015).

During the recent two decades professionals have turned their attention toward cyber-bullying as a specific form of bullying (Hollá et al., 2017; Niklová \& Makúchová, 2018), the expansion of which is connected with the development of information and communication technologies. Other authors have concentrated on bullying prevention (Emmerová, 2009; Flannery et al., 2016). Handling bullying from the aspect of educators is another sub-category of research not so much discussed at the empirical level.

Macháčková (2010) identified deficiencies in intervention strategies for handling initial phases of bullying in teachers from selected elementary schools. Slovenian authors Pečjak \& Pirc (2015) stated that "teachers' perceptions of peer bullying are an important predictor of their intervention". Despite the fact that handling bullying from the aspect of teachers has not been given intense attention, their contribution in the educational practice is unquestionable.

The above fact has led us to monitor teachers' preferred approaches to handling bullying in the conditions of the Slovak Republic. We consider it appropriate for teachers to apply competencies enabling them to intervene in the educational 
reality and correct the consequences of bullying. Research results of De Luca et al. (2019) suggest that if teachers feel competent to address bullying, they use more frequently positive strategies and are more prone to intervene in cases of bullying and victimization.

\section{Methodology}

To map teachers' preferred approaches to handling bullying, the research tool The Handling Bullying Questionnaire (Bauman et al., 2008) was used. The scaled questionnaire was translated by ourselves. 22 original items were preserved and the scale was narrowed from 5 to 4 options (1 - I definitely would not do it, 2 I probably would not do it, 3 - I probably would do it, 4 - I definitely would do it) so that teachers could not evade direct answers choosing the option "I am unsure" making interpretation of the research results difficult.

Exploratory factor analysis was used to understand the internal structure of the tool. The principal components method with a perpendicular rotation Varimax appeared to be the most suitable alternative. The KMO test of sampling adequacy $(0.742)$ and Barlett's test of sphericity $(\mathrm{p}<0.001)$ indicated that application of the factor analysis was suitable for the obtained data. Based on Kaiser's criterion, 5 factors were worked with. The minimum factor loading for an item to be included in one of the factors was 0.30 . On the whole, 6 items were eliminated. Factor loadings of four of them were higher than 0.30 in two or more factors at the same time (I would make sure the bully was punished; I would insist to the bully's parents that the behaviour must stop; I would suggest that the victim act more assertively; I would discuss the matter with my colleagues at school). They were followed by the item with the lowest communality value (I would ignore it). The value mentioned did not exceed the limit of 0.30 . Excluded was also the item the content of which did not fall into the factor of working with the victim (I would explain the bully not to vent the lack of self-esteem on other students). The last two steps enabled the researchers to achieve a higher total variance explained in the variables (51.76\%) against the original one after exclusion of the first 4 items (48.07\%).

Mostly weak dependencies $\left(r_{s}=-0.12-0.28\right)$ were found between the dimensions of the tool. A moderate positive relationship was found only between the dimensions „Working with the bully“ and „Working with the victim“ $\left(\mathrm{r}_{\mathrm{s}}=0.373\right.$; $\mathrm{p}<0.001)$.

Validity of the model as outlined by exploratory factor analysis was then verified using confirmatory factor analysis. The maximum likelihood (ML) estimator was 
Table 1. Preferences of teachers' approaches to handling bullying among students (Rotated matrix of factor loadings)

\begin{tabular}{|c|c|c|c|c|c|c|}
\hline \multirow{2}{*}{ Items loading on factors } & \multicolumn{6}{|c|}{ Factors } \\
\hline & $a$ & I. & II. & III. & IV. & $\mathrm{V}$. \\
\hline (i) Working with the bully & 0.586 & & & & & \\
\hline $\begin{array}{l}\text { I would discuss with the bully options in } \\
\text { order to improve the situation. }\end{array}$ & & 0.743 & 0.015 & 0.058 & -0.008 & 0.123 \\
\hline $\begin{array}{l}\text { I would share my concern with the bully } \\
\text { about what happened to the victim. }\end{array}$ & & 0.633 & 0.236 & 0.025 & 0.111 & 0.178 \\
\hline $\begin{array}{l}\text { I would find the bully something more inter- } \\
\text { esting to do. }\end{array}$ & & 0.622 & 0.172 & 0.115 & 0.039 & -0.192 \\
\hline $\begin{array}{l}\text { I would convene a meeting with students, } \\
\text { tell them what was happening, and ask them } \\
\text { to suggest ways they could help improve the } \\
\text { situation. }\end{array}$ & & 0.498 & 0.098 & 0.160 & -0.157 & 0.179 \\
\hline (ii) Working with the victim & 0.636 & & & & & \\
\hline $\begin{array}{l}\text { I would encourage the victim to show that he } \\
\text { or she could not be intimidated. }\end{array}$ & & 0.183 & 0.749 & 0.050 & 0.044 & 0.049 \\
\hline $\begin{array}{l}\text { I would tell the victim to stand up to the } \\
\text { bully. }\end{array}$ & & 0.003 & 0.743 & 0.066 & -0.011 & 0.030 \\
\hline $\begin{array}{l}\text { I would advise the victim to tell the bully to } \\
\text { „back off”. }\end{array}$ & & 0.255 & 0.715 & 0.092 & 0.020 & 0.028 \\
\hline (iii) Enlisting other adults & 0.625 & & & & & \\
\hline I would refer the matter to the principal. & & 0.029 & 0.054 & 0.806 & -0.010 & 0.046 \\
\hline $\begin{array}{l}\text { I would ask the school counsellor, social } \\
\text { pedagogue, etc. to intervene. }\end{array}$ & & 0.067 & 0.047 & 0.725 & 0.025 & 0.152 \\
\hline $\begin{array}{l}\text { I would contact the victim's parents to ex- } \\
\text { press my concern. }\end{array}$ & & 0.193 & 0.105 & 0.680 & -0.113 & 0.004 \\
\hline (iv) Ignoring the incident & 0.360 & & & & & \\
\hline $\begin{array}{l}\text { I would just tell the kids to „grow up” („cut } \\
\text { it out”). }\end{array}$ & & 0.211 & 0.151 & -0.074 & 0.652 & -0.004 \\
\hline I would leave it for someone else to sort out. & & -0.274 & -0.066 & 0.073 & 0.641 & 0.078 \\
\hline I would treat the matter lightly. & & 0.107 & -0.072 & 0.090 & 0.519 & -0.252 \\
\hline $\begin{array}{l}\text { I would let the students sort it out them- } \\
\text { selves. }\end{array}$ & & -0.059 & 0.032 & -0.130 & 0.502 & 0.008 \\
\hline (v) Disciplining the bully & 0.505 & & & & & \\
\hline I would insist that the bully "cut it out". & & 0.010 & 0.145 & 0.098 & -0.025 & 0.799 \\
\hline $\begin{array}{l}\text { I would make it clear to the bully that his or } \\
\text { her behaviour would not be tolerated. }\end{array}$ & & 0.243 & -0.057 & 0.113 & -0.059 & 0.737 \\
\hline Tool total & 0.649 & & & & & \\
\hline Eigenvalue & & 1.92 & 1.79 & 1.75 & 1.42 & 1.40 \\
\hline$\%$ variance & & 12.02 & 11.21 & 10.96 & 8.85 & 8.72 \\
\hline
\end{tabular}


exploited and indices such as CFI (0.934), TLI (0.914), RMSEA (0.036), SRMR (0.045), and GFI (0.970) were reported. Their values were adjusted by residual covariances between content-corresponding items of the tool (they concerned 2 pairs of items). Significance of the result of the good fit test chi-squared $(p<0.001)$ was confirmed.

The research sample was obtained using convenient sampling. The research was carried out in all Slovak regions in 2020 (March - June). 924 respondents participated in the research. After elimination of respondents with short experience (of a few months to one year) and those who were not the target group of our research, the sample of 696 teachers was worked with (see T2).

Table 2. Characteristics of the research sample

\begin{tabular}{|c|c|c|}
\hline $\begin{array}{l}\text { Demographic characteristics } \\
\text { of the research sample }\end{array}$ & $\mathrm{N}$ & $\%$ \\
\hline \multicolumn{3}{|l|}{ Gender } \\
\hline Males & 67 & 9.63 \\
\hline Females & 629 & 90.37 \\
\hline \multicolumn{3}{|l|}{ Teaching qualification obtained through } \\
\hline Teacher study programme at a higher education institution & 629 & 90.37 \\
\hline Supplementary pedagogical study supplementing teaching & 67 & 9.63 \\
\hline \multicolumn{3}{|l|}{ Class teacher duties } \\
\hline Yes & 475 & 68.25 \\
\hline No & 221 & 31.75 \\
\hline \multicolumn{3}{|l|}{ Anti-bullying training received } \\
\hline Yes & 238 & 34.20 \\
\hline No & 458 & 65.80 \\
\hline \multicolumn{3}{|l|}{ Another function performed } \\
\hline Functions not aimed at sorting out problem behaviour & 404 & 58.05 \\
\hline Functions aimed at sorting out problem behaviour & 177 & 25.43 \\
\hline School administrators & 115 & 16.52 \\
\hline \multicolumn{3}{|l|}{ Length of experience in completed years } \\
\hline $0-5$ & 60 & 8.62 \\
\hline $6-10$ & 76 & 10.92 \\
\hline $11-15$ & 85 & 12.21 \\
\hline $16-20$ & 128 & 18.39 \\
\hline $21-25$ & 98 & 14.08 \\
\hline $26-30$ & 93 & 13.36 \\
\hline 31 and more & 156 & 22.41 \\
\hline
\end{tabular}


We asked the following research questions:

Is there a statistically significant difference in teachers' preferred approaches to handling bullying by gender?

Is there a statistically significant difference in teachers' preferred approaches to handling bullying by the way they obtained their qualification?

Is there a statistically significant difference in teachers' preferred approaches to handling bullying by the function of class teacher?

Is there a statistically significant difference in teachers' preferred approaches to handling bullying by anti-bullying training?

Is there a statistically significant difference in teachers' preferred approaches to handling bullying by their other functions?

Is there a statistically significant relationship between teachers' preferred approaches to handling bullying and the length of their experience?

Statistically significant differences and relationships between variables were evaluated using non-parametric tests such as Mann-Whitney's test, Kruskal-Wallis' test and Spearman's correlation coefficient, since normal distributions of the variables in sets and sub-sets were not confirmed which was verified by Kolmogorov-Smirnov's test $(\mathrm{p}<0.05)$. The chosen level of significance was 0.05 . Practical significance of the differences was determined by eta-squared $\left(\eta^{2}\right)$. The arithmetic mean (AM) and median (Me) were used for descriptive statistics. Statistical analysis of the data was conducted with the programs SPSS 20.0 and JASP 0.14.1.

\section{Results of research}

Table 3. Statistically significant differences and relationship between variables

\begin{tabular}{llllll}
\hline \multicolumn{1}{c}{ Variables } & \multicolumn{5}{c}{ Dimensions } \\
\hline Independent & $\begin{array}{l}\text { Working } \\
\text { with the } \\
\text { bully }\end{array}$ & $\begin{array}{c}\text { Working } \\
\text { with the } \\
\text { victim }\end{array}$ & $\begin{array}{c}\text { Enlisting } \\
\text { other adults }\end{array}$ & $\begin{array}{c}\text { Ignoring } \\
\text { the incident }\end{array}$ & $\begin{array}{c}\text { Disciplin- } \\
\text { ing the } \\
\text { bully }\end{array}$ \\
\hline Gender & - & - & - & - & $*$ \\
\hline $\begin{array}{l}\text { Obtaining teaching qualifi- } \\
\text { cation }\end{array}$ & - & - & $*$ & $*$ & $*$ \\
\hline Class teacher duties & $*$ & - & - & - & - \\
\hline $\begin{array}{l}\text { Received anti-bullying } \\
\text { training }\end{array}$ & $*$ & - & $*$ & - & - \\
\hline Performed another function & - & - & - & $*$ & - \\
\hline $\begin{array}{l}\text { Length of experience in } \\
\text { completed years }\end{array}$ & $*$ & - & - & - & \\
\hline
\end{tabular}


It follows from T3 that male respondents scored statistically significantly higher than female respondents on the dimension "Disciplining the bully" $(0.016 \leq 0.05$; Mann-Whitney's U test $=18953.000 ; A M=3.99 ; A M=3.89)$. Not even a weak effect was found of the differences in resulting values $\left(\eta^{2}=0.003\right)$.

Respondents having obtained their teaching qualification through a supplementary pedagogical study scored statistically significantly lower on the dimension "Ignoring the incident" (0.001 $\leq 0,05$; Mann-Whitney's U test $=16210.500$; $\mathrm{Me}=1.00 ; \mathrm{Me}=1.25)$ while scoring statistically significantly higher on the dimensions „Enlisting other adults“ ( $0.049 \leq 0.05$; Mann-Whitney's U test = 18111.500; $\mathrm{AM}=3.64 ; \mathrm{AM}=3.48)$ and "Disciplining the bully“ (0.016 $\leq 0.05$; Mann-Whitney's $\mathrm{U}$ test $=18953.000 ; \mathrm{AM}=3.99 ; \mathrm{AM}=3.89$ ) when compared with respondents having obtained their teaching qualification through a teacher study programme at a higher education institution. In the former case, a weak effect was observed of the differences in resulting values; and in the latter cases, for a change, not even a weak effect of the differences in resulting values $\left(\boldsymbol{\eta}^{2}=0.014 ; 0.005 ; 0.003\right)$ was found.

Respondents with class teacher duties scored statistically significantly higher on the dimension "Working with the bully“ $(0,018 \leq 0.05$; Mann-Whitney's U test = 46705.500; $\mathrm{Me}=3.50 ; \mathrm{Me}=3.25$ ) than respondents who were not class teachers. Not even a weak effect was found of the differences in resulting values $\left(\eta^{2}=0.008\right)$.

Respondents having received anti-bullying training within their continuing education scored statistically significantly higher on the dimensions „Working with the bully" $(0.015 \leq 0.05$; Mann-Whitney's $\mathrm{U}$ test $=48422.000 ; \mathrm{Me}=3.50$; $\mathrm{Me}=3.25)$ and „Enlisting other adults“ $(0.002 \leq 0.05$; Mann-Whitney's U test = 46939.500; $\mathrm{AM}=3.59 ; \mathrm{AM}=3.44$ ) in comparison with respondents not having received such training. One weak effect of the differences in resulting values $\left(\eta^{2}=0.008 ; 0.013\right)$ was found.

Based on the data presented in T3 we state that there is a statistically significant difference in the preference of the indifferent approach to handling bullying by performance of teachers' other functions $(0.003 \leq 0.05$; Kruskal-Wallis' H test = 11.695). The lowest scores on the given dimension were from respondents performing functions aimed at sorting out students' problem behaviour $(\mathrm{Me}=1.00$; $\mathrm{Me}=1.25 ; \mathrm{Me}=1.25)$. A weak effect of the differences in resulting values $\left(\boldsymbol{\eta}^{2}=\right.$ 0.014 ) was found.

T3 also shows that there is a statistically significant weak positive relationship between the lengths of teachers' experience and teachers' approach to handling bullying through working with the bully $\left(0.000 \leq 0.05 ; \mathrm{r}_{\mathrm{s}}=0.183\right)$. 


\section{Discussion}

On the basis of international research, Rigby (2014) concluded that a substantial portion of students continue to be bullied at school after they have sought help from teachers. Teachers are key players it this area (Gregus et al., 2017), but we have to ask what means they use to eliminate bullying, because these means are often behind the effectiveness of its management.

Although no statistically significant differences by gender were determined in teachers' preferences of more active approaches to handling bullying, male teachers were considerably more inclined to intervene against the bully through disciplining him or her. Research results presented by Burger et al. (2015) showed that female teachers were likely to work with bullies more than male teachers who were more likely to prefer to ignore the incident. The reason worth consideration may lie also in teachers' classroom management skills. In their study, Ahmed et al. (2018) concluded that female teachers scored statistically significantly higher than male teachers on 4 of 6 dimensions of their Classroom Management Inventory.

Teachers having obtained their qualification through a supplementary pedagogical study criticized "Ignoring the incident" and preferred "Disciplining the bully" and „Enlisting other adults“. Research results of Small et al. (2013) showed that diploma-qualified teachers perceived physical bullying to be more serious than verbal and relational bullying than university degree-qualified teachers. On the other hand, university-degree teachers would be more likely to intervene in such behaviour. Since the training is less complex in a supplementary pedagogical study, teachers may have shown tendencies to deal with student problem behaviour using formal authority; however, it is a prompt response suppressing bullying in the bud.

"Working with the bully" was preferred more by class teachers than those who did not hold this position. Pétiová (2014) whose research was aimed at assessing the existing situation and changes in the area of bullying among students in the school setting from 2005 to 2014, stated that answers of respondents showed, besides the fact that bullying was most often dealt with by the victim's class teacher and parents, also that the most frequent way of dealing with serious violent behaviour was a talk with the bully also on the part of the class teacher.

"Working with the bully" and "Enlisting other adults" - competent persons was preferred more by teachers having received anti-bullying training. According to Bauman's et al. (2008) research results, teachers who had anti-bullying training scored statistically significantly lower on the dimension "Ignoring the incident" in comparison with teachers not having such training. 
The indifferent approach appears to be the least suitable approach to handling bullying for teachers with functions aimed at sorting out student problem behaviour than for teachers with the other two functions. In the preference of approaches, Bauman et al. (2008) identified a statistically significant difference in "Ignoring the incident" and „Disciplining the bully" in favour of teachers, and "Working with the victim" in favour of school counsellors.

Taking into account the practical significance of the differences, the above mentioned independent variables are not in the position of determinants deciding on teachers' preferred approaches to handling bullying. The length of teachers' experience is likely more important.

Burger's et al. (2015) research results indicated that the most experienced teachers preferred working with the bully and the victim considerably more than those who had the least experience (of less than 6 years). The research by Sairanen \& Pfeffer (2011) also emphasized the significance of teachers' experience. Teachers with over than 20 years of experience reported that they would specifically work with the bully in comparison with teachers with less than ten years' experience in education. Multilevel analyses of data, performed in the research by Wachs et al. (2019) also showed that supportive-cooperative intervention strategies were more successful in dealing with bullying in both the short and long term.

In connection with the empirical findings, more intense future research activities would be useful, aimed at verification of the effectiveness of the above mentioned teachers' intervention strategies for handling bullying, taking into account also its expansion into the digital space. Also, it is necessary to pay attention to the analysis of teachers' needs in this area, which may contribute to their preparedness to face bullying at school adequately.

\section{References}

Ahmed, M., Ambreen, M., \& Hussain, I. (2018). Gender Differentials Among Teachers' Classroom Management Strategies In Pakistani Context. Journal of Education and Educational Developement, 5(2), 178-193. DOI: 10.22555/joeed.v5i2.2253

Bauman, S., Rigby, K., \& Hoppa, K. (2008). US teachers' and school counsellors' strategies for handling school bullying incidents. Educational Psychology, 28(7), 837-856. http:// dx.doi.org/10.1080/01443410802379085

Burger, C., Strohmeier, D., Spröber, N., Bauman, S., \& Rigby, K. (2015). How teachers respond to school bullying: An examination of self-reported intervention strategy use, moderator effects, and concurrent use of multiple strategies. Teaching and Teacher Education, 51, 191-202. https://doi.org/10.1016/j.tate.2015.07.004

Craig, W., Harel-Fisch, Y., Fogel-Grinvald, H., Dostaler, S., Hetland, J., Simons-Morton, 
B., Molcho, M., de Mato, M.G., Overpeck, M., Due, P., Pickett, W., the HBSC Violence \& Injuries Prevention Focus Group, \& the HBSC Bullying Writing Group. (2009). A cross-national profile of bullying and victimization among adolescents in 40 countries. Int J Public Health, 54(Suppl 2), 216-224. https://doi.org/10.1007/s00038-009-5413-9

De Luca, L., Nocentini, A., \& Menesini, E. (2019). The Teacher's Role in Preventing Bullying. Frontiers in Psychology, 10, 1830, 1-9. https://doi.org/10.3389/fpsyg.2019.01830

Due, P., Holstein, B.E., Lynch, J., Diderichsen, F., Gabhain, S.N., Scheidt, P., Currie, C., \& The Health Behaviour in School-Aged Children Bullying Working Group. (2005). Bullying and symptoms among school-aged children: International comparative cross sectional study in 28 countries. The European Journal of Public Health, 15(2), 128-132.

Emmerová, I. (2009). Bullying of Pupils at Primary and Secondary Schools and its Prevention in the School Environment in the Slovak Republic. The New Educational Review, 19(3-4), 182-192.

Flannery, D.J., Todres, J., Bradshaw, C.P., Amar, A.F., Graham, S., Hatzenbuehler, M., Masiello, M., Moreno, M., Sullivan, R., Vaillancourt, T., Le Menestrel, S.M., \& Rivara, F. (2016). Bullying Prevention: a Summary of the Report of the National Academies of Sciences, Engineering, and Medicine. Prevention Science, 17, 1044-1053. https://doi. org/10.1007/s11121-016-0722-8

Gregus, S.J., Hernandez Rodriguez, J., Pastrana, F.A., Craig, J.T., McQuillin, S.D., \& Cavell, T.A. (2017). Teacher Self-Efficacy and Intentions to Use Antibullying Practices as Predictors of Children's Peer Victimization. School Psychology Review, 46(3), 304-319.

Hollá, K., Fenyvesiová, L., \& Hanuliaková, J. (2017). Measurement of Cyber-Bullying Severity. The New Educational Review, 47(1), 29-38.

Hymel, S., \& Swearer, S.M. (2008). Bullying: An Age-Old Problem That Needs New Solutions. Educational Psychology Papers and Publications. 1-5.

Jan, A., \& Husain, S. (2015). Bullying in Elementary Schools: Its Causes and Effects on Students. Journal of Education and Practice, 6(19), 43-56.

Kartal, H., \& Bilgin, A. (2009). Bullying and School Climate from the Aspects of the Students and Teachers. Eurasian Journal of Educational Research, 36, 209-226.

Macháčková, P. (2010). Selected Basic Schools Pedagogical Workers' Preparedness for Bullying in School Environment. The New Educational Review, 21(2), 218-235.

Nansel, T.R., Overpeck, M., Pilla, R.S., Ruan, W.J., Simons-Morton, B., \& Scheidt, P. (2001). Bullying Behaviors Among US Youth Prevalence and Association With Psychosocial Adjustment. Journal of the American Medical Association, 285(16), 2094-2100. doi:10.1001/jama.285.16.2094

Niklová, M., \& Makúchová, J. (2018). Forms of Cyber-bullying from the Aspect of Cyber-victims - Elementary and Secondary School Pupils. The New Educational Review, 51(1), 150-161.

Pečjak, S., \& Pirc, T. (2015). Predictors and Forms of Intervention in Peer Bullying: Pre-service Teachers vs. Teachers. The New Educational Review, 39(1), 264-276.

Pétiová, M. (2014). Šikanovanie $v$ základných a stredných školách. Záverečná správa 
z výskumu. (Bullying in Elementary and Secondary Schools. Final research report) Bratislava: CVTI SR.

Rigby, K. (2014). How teachers address cases of bullying in schools: a comparison of five reactive approaches. Educational Psychology in Practice, 30(4), 409-419. https://doi.org /10.1080/02667363.2014.949629

Sairanen, L., \& Pfeffer, K. (2011). Self-reported handling of bullying among junior high school teachers in Finland. School Psychology International, 32(3), 330-344. https://doi. org $/ 10.1177 / 0143034311401795$

Small, P., Neilsen-Hewett, C., \& Sweller, N. (2013). Individual and Contextual Factors Shaping Teachers' Attitudes and Responses to Bullying among Young Children: Is Education Important? Asia-Pacific Journal of Research in Early Childhood Education, 7(3), 69-101. https://ro.uow.edu.au/sspapers/3929/

Twardowska-Staszek, E., Zych, I., \& Ortega-Ruiz, R. (2018). Bullying and cyberbullying in Polish elementary and middle schools: Validation of questionnaires and nature of the phenomena. Children and Youth Services Review, 95, 217-225. https://doi.org/10.1016/j. childyouth.2018.10.045

Wachs, S., Bilz, L., Niproschke, S., \& Schubarth, W. (2019). Bullying Intervention in Schools: A Multilevel Analysis of Teachers' Success in Handling Bullying From the Students' Perspective. The Journal of Early Adolescence, 39(5), 642-668. https://doi. org/10.1177/0272431618780423 